УДК 336.22:330.524.4

Скрипник Г.О., к.е.н., доцент

Цюпа С.В., магістр

Національний університет біоресурсів і природокористування України

\title{
ТРЕНДОВА МОДЕЛЬ ЗАЛЕЖНОСТІ РОЗМІРУ ВВП ВІД НАДХОДЖЕНЬ ДО БЮДЖЕТУ
}

Розвиток ринкових відносин зумовив загострення уваги на проблемних питаннях регулювання державних фінансів загалом і побудови зваженої та ефективної бюджетної політики зокрема. В умовах динамічних змін у економічному середовищі бюджет являє собою не лише централізований фонд фінансових ресурсів держави, а й $є$ важливим інструментом впливу як на макроекономічний стан i стабільний економічний розвиток кожної країни загалом, так і на стійке економічне зростання окремих ії суб'єктів господарювання. В статті розглянуто показники надходжень до бюджету та їх залежність від розміру ВВП.

В роботі запропонована трендова модель показує чи присутня залежність ВВП від надходжень бюджету і подальший прогноз цієї залежності відповідно.

Ключові слова: валовий внутрішній продукт; зведений бюджет; податкові надходження; неподаткові надходження, трендове прогнозування.

Skrypnyk H., Tsiupa S.

\section{TREND MODEL OF DEPENDENCE OF GDP DIMENSION FROM ADMINISTRATIVE REVENUE TO THE BUDGET}

The development of market relations has led to an intensification of attention to problematic issues of regulating public finances in general and the construction of a balanced and effective budget policy in particular. In conditions of dynamic changes in the economic environment, the budget is not only a centralized fund of financial resources of the state, but is also an important instrument of influence both on the macroeconomic status and stable economic development of each country as a whole, as well as on the steady economic growth of its individual economic entities. The article considers the indicators of budget revenues and their dependence on the size of GDP.

In this paper, the proposed trend model shows whether the dependence of GDP on budget revenues and the subsequent forecast of this dependence, respectively, are present.

Keywords: gross domestic product; consolidated budget; tax receipts; non-tax receipts, trend forecasting.

Скрипник Г.А., Цюпа С.В.

\section{ТРЕНДОВАЯ МОДЕЛЬ ЗАВИСИМОСТИ РАЗМЕРА ВВП ОТ ПОСТУПЛЕНИЙ В БЮДЖЕТ}

Развитие рыночных отношений обусловил обострение внимания на проблемных вопросах регулирования государственных финансов в целом и построения взвешенной и эффективной бюджетной политики в частности. В условиях динамических изменений в экономической среде бюджет является не только централизованным фондом финансовых ресурсов государства, но и является важным инструментом влияния как на макроэкономическое состояние и стабильное экономическое развитие каждой страны в целом, так и на устойчивый экономический рост отдельных ее субъектов. В статье рассмотрены показатели поступлений в бюджет и их зависимость от размера ВВП.

В работе предложена трендовая модель показывает присутствует зависимость ВВП от поступлений бюджета и дальнейший прогноз этой зависимости соответственно.

Ключевые слова: валовой внутренний продукт; сводный бюджет; налоговые поступления; неналоговые поступления, трендовое прогнозирование.

Постановка проблеми у загальному вигляді i iï зв'язок 3 важливими науковими та практичними завданнями. Сьогодні фінансові ресурси держави $\epsilon$ важливим фінансовим інструментом, який найкраще характеризує параметри економіки (доходи і витрати бюджету, державні запозичення тощо) і ставить конкретні завдання для розвитку національної економіки України. Саме ці кошти забезпечують соціальноекономічний розвиток України і її окремих регіонів. Тому основним завдання держави $\epsilon$ 
вдале формування фінансових ресурсів i їх цільове використання. Тому ця збалансованість між витрачанням і надходженнями коштів повинна контролюватися, оскільки це може призвести до економічної кризи, збільшення державного боргу, дефіцитів бюджетів усіх рівнів тощо.

Вдала рівновага між формуванням i використанням дозволила би державі використовувати тільки внутрішні джерела наповнення бюджету за допомогою податкових надходжень, неподаткових надходжень, цільових фондів, доходів від операцій $з$ капіталом та інших коштів. Але якщо внутрішніх джерел наповнення державного бюджету мало, можна використати державні запозичення. Проте це буде збільшувати дефіцит бюджету і збільшуватиме державний борг. Розробка і реалізація заходів щодо контролю надходжень до зведеного бюджету потребує адекватного методичного забезпечення прогнозування наслідків діяльності держави в макроекономічному масштабі.

Аналіз останніх досліджень і публікацій, у яких започатковано вирішення проблеми. Важливу роль для з'ясування основних теоретичних питань фінансових ресурсів держави відіграли праці відомих вчених фінансистів: Н. І. Коваленко [2], О. Д. Василик [1], Г. Я. Шахова [4], В. М. Федосова [3]. Для визначення процесу формування бюджетних ресурсів в сучасних умовах, заслуговують уваги роботи Т. Л. Фролової [5] та О.О. Рожко [6] та багато інших науковців. Для економіко-математичних розрахунків знадобилися праці таких сучасних вчених як В. С. Григорків $[7,8]$ та О. Ю. Вінничук [9]. Проте проблема формування бюджетних ресурсів держави і їх використання в умовах економічної кризи не $є$ достатньо розкритою, що вимагає подальшого іiі дослідження.

Цілі статті. Метою даної статті є з'ясування залежності розміру ВВП від основних показників надходжень бюджету та їх прогнозу. Для досягнення даної мети були виконані наступні задачі:

- дослідити основні показники надходжень бюджету та розмір ВВП протягом 20152017 pp.;

- побудувати рівняння лінійного множинного кореляційно-регресійного зв'язку;

- здійснити трендове прогнозування залежності ВВП від показників надходження бюджету;

- на основі здійсненого прогнозування з'ясувати чи така залежність $є$ і чи придатна вона для здійснення макроекономічних дослідів.

Виклад основного матеріалу дослідження 3 повним обгрунтуванням отриманих наукових результатів. Державні фінанси функціонують на чітко визначених умовах і формуються за рахунок фінансів підприємств та організацій державної і комунальної форм власності. За рахунок цього джерела створюється майже 35 \% валового внутрішнього продукту, який є головним об'єктом фінансового розподілу. За умов переходу до ринкових відносин частка державного сектору економіки з року в рік істотно зменшується, проте ще на сьогодні цей сектор відіграє ключову роль у формуванні, розподілі, перерозподілі та використанні фінансових ресурсів держави.

Однією 3 найважливіших умов розкриття змісту й призначення фінансових ресурсів $\epsilon$ виявлення їхнього взаємозв'язку 3 вартісною структурою валового внутрішнього продукту. В останні роки динаміка ВВП постійно зростає. Але це знижує, 3 одного боку, ефективність самої фінансової системи, а 3 другого - негативно позначається на наявній системі розподілу й перерозподілу створюваного продукту (зокрема, перевантаження фінансової системи різними формами перерозподілу ресурсів між верствами населення).

Для проведення аналізу особливостей впливу основних економічних факторів на ВВП в Україні, застосуємо економіко-математичні методи, а саме - кореляційнорегресійний аналіз. Основною метою кореляційного аналізу є встановлення причинних залежностей між явищами, які зумовлені складним комплексом різних за характером i сутністю причин. Перед тим, як побудувати багатофакторну економетричну модель, 
визначимо перелік факторів, які мають вплив на динаміку ВВП:

1. Податкові надходження - визнаються встановлені законами України про оподаткування загальнодержавні податки і збори та місцеві податки і збори.

2. Неподаткові надходження - доходи від власності та підприємницької діяльності; адміністративні збори та платежі, доходи від некомерційної господарської діяльності; інші неподаткові надходження.

3. Доходи від операиій з капіталом.

4. Офіційні трансферти - кошти, одержані від інших органів державної влади, органів влади Автономної Республіки Крим, органів місцевого самоврядування, інших держав або міжнародних організацій на безоплатній та безповоротній основі [11].

У більшості випадків економічні показники залежать не від одного, а від багатьох сукупно діючих факторів. В нашому випадку на рівень впливають величезний ряд факторів, проте досліджувати ми будемо наступні: податкові надходження; неподаткові надходження; доходи від операцій з капіталом; офіційні трансферти (табл. 1).

Теоретичне рівняння лінійного множинного кореляційно-регресійного зв'язку формалізується так:

$$
Y=\alpha+\beta_{1} X_{1}+\beta_{2} X_{2}+\beta_{3} X_{3}+\beta_{4} X_{4}
$$

де: $\mathrm{Y}$ - залежна змінна, $\mathrm{X} 1, \ldots, \mathrm{X} 4$ - незалежні змінні (фактори), $\alpha, \beta_{1}, \ldots, \beta_{4}-$ невідомі параметри.

Таблиця 1.

Вихідні дані для моделювання залежностей основних факторів ВВП від бюджетних параметрів

\begin{tabular}{|l|c|c|c|}
\hline \multicolumn{1}{|c|}{ Показник } & 2015 p. & 2016 p. & 2017 p. \\
\hline \multicolumn{1}{|c|}{1} & 2 & 3 & 4 \\
\hline ВВП (Y) & 1430290 & 2034430 & 2445587 \\
\hline Податкові надходження (X1) & 409417,5 & 503879,4 & 627153,7 \\
\hline Неподаткові надходження (X2) & 120006,5 & 103635,2 & 128402,3 \\
\hline Доходи від операцій з капіталом (X3) & 171,4 & 191,5 & 286,9 \\
\hline Офіційні трансферти (X4) & 3144,0 & 4171,6 & 5967,7 \\
\hline
\end{tabular}

* побудовано за джерелом [10]

Таким чином, процес моделювання зводиться до визначення параметрів $\alpha, \beta_{1}, \ldots, \beta_{4}$. Стандартним способом вирішення даної проблеми $\epsilon$ застосування методу найменших квадратів, що зводить пошук значень параметрів $\alpha, \beta_{1}, \ldots, \beta_{4}$ до розв'язання системи рівнянь. Сучасне програмне забезпечення, зокрема матричний процесор MS Excel, дозволяє розв'язувати подібні системи рівнянь за методом Крамера. Для пошуку параметрів регресії, застосовуємо в процесорі Excel функції ТРАНСП, МУМНОЖ, МОБР.

Тоді лінійне множинне кореляційно-регресійне рівняння матиме такий вигляд:

$\hat{y}=3145728-5,1 * X 1-8 * X 2-8192 * X 3+768 * X 4$

Для виконання трендового прогнозування, потрібно підрахувати згладжене значення Y, тоді ж можна спрогнозувати дані на два роки.

Розраховуємо стандартну помилку рівняння $\left(\mathrm{S}_{\Gamma}\right)$ за такою формулою:

$$
S_{r}=\sqrt{\frac{\sum\left(y_{t}-\hat{y}_{t}\right)^{2}}{n-2}} \quad \text { (2.9) або } S_{r}=\sqrt{\frac{\sum y_{t}^{2}-a \sum y_{t}-b \sum t y_{t}}{n-2}} .
$$

Звідси $\mathrm{S}(\mathrm{r})=492690,5$.

Розраховуємо стандартну помилку прогнозу $\left(S_{\hat{y}_{t+\tau}}\right)$ за такою формулою:

$S_{\hat{y}_{t+\tau}}=\sqrt{\frac{\sum y_{t}^{2}-a \sum y_{t}-b \sum y_{t}}{n-2}} \cdot \sqrt{1+\frac{1}{n}+\frac{\left(\tau+\frac{n-1}{2}\right)^{2}}{\sum\left(t-\bar{t}^{2}\right)}}, \quad$ де $T-$ період прогнозування. 
Таблиця 2.

Результати прогнозування з врахуванням довірчого інтервалу

\begin{tabular}{|c|c|c|c|c|c|c|}
\hline \multirow{2}{*}{$\begin{array}{c}\text { Період, } \\
\text { роки }\end{array}$} & \multirow{2}{*}{$\begin{array}{c}\text { Період } \\
\text { прогнозу } \\
\text { вання, } T\end{array}$} & \multirow{2}{*}{$\begin{array}{c}\text { Фактичне } \\
\text { значення } \\
y_{t}\end{array}$} & \multirow{2}{*}{$\begin{array}{l}\text { Згладжене } \\
\text { значення i } \\
\text { прогноз } \hat{y}_{t}\end{array}$} & \multirow{2}{*}{$\begin{array}{c}\text { Стандартна } \\
\text { помилка } \\
\text { прогнозу }\end{array}$} & \multicolumn{2}{|c|}{$95 \%$ довірчий інтервал } \\
\hline & & & & & нижня границя & $\begin{array}{c}\text { верхня } \\
\text { границя }\end{array}$ \\
\hline 1 & 2 & 3 & 4 & 5 & 6 & 7 \\
\hline$\overline{t_{1}}$ & $\overline{-2}$ & 1430290 & 1110689 & 1,6 & $-1576609,581$ & 1576609,581 \\
\hline$\overline{t_{2}(\bar{t})}$ & -1 & 2034430 & 1385032 & 1,1 & $-1083919,087$ & 1083919,087 \\
\hline$t_{3}$ & 0 & 2445587 & 1156854 & 1,6 & $-1576609,581$ & 1576609,581 \\
\hline $\mathrm{t}_{4}$ & 1 & - & 1385032 & 3,1 & $-1734942,26$ & 1734942,26 \\
\hline$t_{5}$ & 2 & - & 1613209 & 5,6 & $-2331837,02$ & 2331837,02 \\
\hline
\end{tabular}

* побудовано за табл.1

Визначаємо дев'яносто п'ятивідсоткові довірчі інтервали, які будуть дорівнювати $\pm 2 S_{\hat{y}_{t+\tau}}$. Одержані результати прогнозування 3 урахуванням довірчих інтервалів приведемо у вигляді графіку рис. 1).

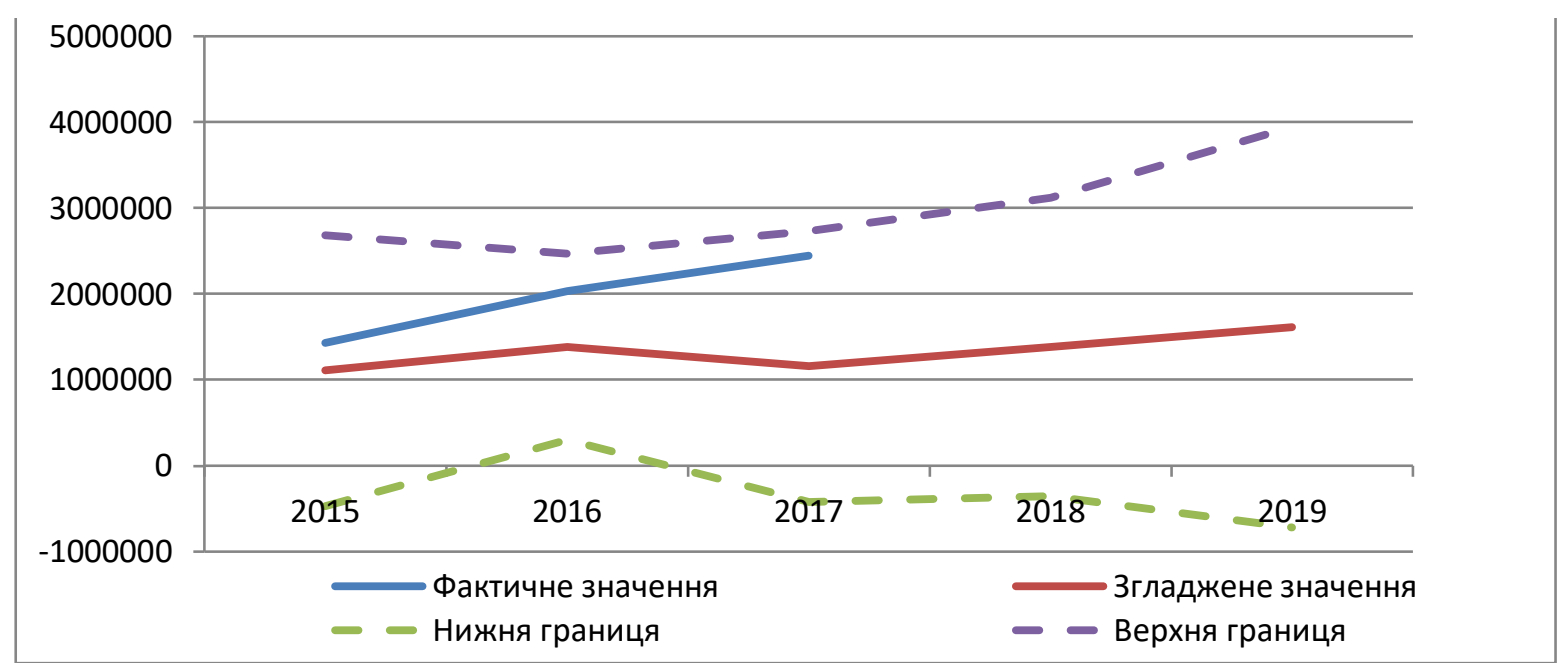

Рис. 1. Прогнозування розміру ВВП в залежності від надходжень зведеного бюджету на 2015-2019 pp.

На основі проведеного дослідження, можна зазначити, що кореляційно-регресійна залежність між ВВП та надходженнями до зведеного бюджету присутня, i, по економікоматематичних розрахунках розмір ВВП дуже коливається, оскільки згладжене значення набагато відрізняється від фактичного. Проте спостерігається позитивна тенденція росту ВВП — головного індикатору економічного розвитку і найповніший показник сумарного обсягу виробництва товарів та послуг за певний період.

Висновки. Отже, на основі показників надходжень до бюджету можна спрогнозувати розмір ВВП і використовувати його для макроекономічних дослідів. Проте для ширшого дослідження, потрібно враховувати більше показників надходжень бюджету, тим самим зробити більш скориговану та точну залежність.

Таким чином, прогнозування доходів бюджету $\epsilon$ основою для планування розвитку державних фінансів. Впровадження уточнених розрахунків надходжень до бюджету дозволяє визначити оптимальний обсяг і раціональну структуру його видатків. Результати досліджень, представлені в цій статті, $є$ важливими для реалізації політики державних фінансів.

Використання сучасних підходів до прогнозування надходжень до бюджету є запорукою підвищення ефективності фінансової політики держави. Тобто для того, щоб отримати найбільш вірогідні прогнози, необхідно поєднати різні методи прогнозування 
(експертне, статистичне, математичне моделювання), що допоможе зменшити фінансові ризики і забезпечити прогнозування коливань на етапі їх виконання.

\section{Список використаних джерел:}

1.Василик О. Д. Теорія фінансів. Підручник. 4-те вид., доп. /О. Д. Василик. - Київ: НЮС, 2003. - 416 с.

2.Коваленко Н. І. Еволюція теоретичних поглядів щодо сутності фінансових ресурсів держави / Н. І. Коваленко. // Економіка та держава. - 2012. - №12. - С. 42-44.

3.Федосов В. Фінансова реструктуризація в Україні: проблеми і напрями: монографія / В. Федосов, В. Опарін, С. Льовочкін. - Київ: КНЕУ, 2002. - 387 с.

4.Шахова Г. Я. Финансовые ресурсы в системе макроэкономических взаимосвязей / Г. Я. Шахова. // Финансы. - 1993. - №3. - C. 3-11.

5.Фролова Т.Л. Фінансовий ресурс розвитку національної економіки: формування та пріоритетні напрями використання // Міжнародна економічна політика. - 2016 [Електронний ресурс] - Режим доступ: http://iepjournal.com/journals/25/2016_7_Frolova_Lukianenko_Otchenash.pdf

6.Рожко О. О. Специфіка формування фінансових ресурсів держави в умовах економічної кризи // Економіка. - 2013. [Електронний ресурс] - Режим доступу до pecypcy: http://bulletin-econom.univ.kiev.ua/wpcontent/uploads/2015/11/132_13.pdf.

7.Григорків В. С. Економетрика: лаб. практикум. / В. С. Григорків, О. Ю. Вінничук. - Чернівці: Вид. 2-ге, перероб. та допов., 2015. $-96 \mathrm{c}$

8.Григорків В. С. Методи моделювання в умовах інформаційного суспільства // Сучасні інформаційні технології у бізнесі та досвід їх використання: матеріали Всеукраїнської школи-семінару / В. С. Григорків, 2017. - 25 с.

9.Вінничук О.Ю. Дослідження економічного зростання в умовах сталого розвитку: нейромережевий підхід / О. Ю. Вінничук // Науковий вісник Чернівецького університету: зб. наук. праць. - Чернівці: Чернівецький нац. ун-т. - 2014. - Вип. 694-695. Економіка. - С. 162-165

10. Індекси Міністерства фінансів України [Електронний ресурс]. - Режим доступу: https://index.minfin.com.ua/ua/ 11. Бюджетний кодекс України [Електронний ресурс] - Режим доступу: https://zakon.rada.gov.ua/laws/show/2456-17. Рещензент д.е.н., професор Давиденко Н.М.

\section{УДК 336.77}

Чиж Н.М., к.е.н., доцент

Мостовенко Н.А., к.е.н, доцент

Коробчук T.I., к.е.н., доцент

Луцький національний технічний університет

\section{ОЦІНКА ДЖЕРЕЛ ФОРМУВАННЯ РЕСУРСНОЇ БАЗИ БАНКІВ В УКРАЇНІ}

У статті проведено оцінку джерел ресурсної бази банківської системи України. Проаналізовано динаміку та сучасний стан ресурсної бази вітчизняних банків. Визначена заходи стабілізації банківської системи України.

Ключові слова: ресурсна база, банк, банківська система, банківські ресурси, власний капітал, зобов’язання, кошти фізичних осіб, кошти юридичних осіб.

Chyzh N., Mostovenko N., Korobchuk T.

\section{ASSESSMENT OF SOURCES FORMING THE RESOURCE BASE OF BANKS IN UKRAINE}

The article assesses sources of resource base of the banking system of Ukraine. The dynamics and current state of the resource base of domestic banks are analyzed. The measures of stabilization of the banking system of Ukraine are determined.

Keywords: resource base, bank, banking system, bank resources, own capital, liabilities, funds of individuals, funds of legal entities.

Чиж Н.М., Мостовенко Н.А., Коробчук Т.И.

\section{ОЦЕНКА ИСТОЧНИКОВ ФОРМИРОВАНИЯ РЕСУРСНОЙ БАЗЫ БАНКОВ В УКРАИНЕ}

В статье проведено оценка источников ресурсной базы банковской системы Украины. Проанализирована динамика и современное состояние ресурсной базы отечественных банков. Определенная меры стабилизации банковской системы Украины. 